\title{
Effects of harvest time and added molasses on nutritional content, ensiling characteristics and in vitro degradation of whole crop wheat
}

\author{
Chuanqi Xia ${ }^{1, a}$, Yixun Liang ${ }^{1, a}$, Sarula Bai ${ }^{1}$, Yang He ${ }^{1}$, Aziz Ur Rahman Muhammad ${ }^{1,2}$, \\ Huawei $\mathrm{Su}^{1, *}$, and Binghai $\mathrm{Cao}^{1, *}$
}

\author{
* Corresponding Authors: \\ Huawei Su \\ Tel: +86-010-62814346, Fax: +86-010-62814346, \\ E-mail: su_huawei@foxmail.com \\ Binghai Cao \\ Tel: +86-010-62814346, Fax: +86-010-62814346, \\ E-mail: caobinghai@163.com \\ 'State Key Laboratory of Animal Nutrition, College of \\ Animal Science and Technology, China Agricultural \\ University, Beijing 100193, China \\ 2 Institute of Animal and Dairy Sciences, University of \\ Agriculture Faisalabad, Faisalabad 3800, Pakistan \\ a These authors contributed equally to this work. \\ ORCID \\ Huawei Su \\ https://orcid.org/0000-0001-9934-9576 \\ Binghai Cao \\ https://orcid.org/0000-0001-5084-8497
}

Submitted Jul 21, 2017; Revised Aug 28, 2017; Accepted Sept 29, 2017
Objective: Wheat is an alternative to corn silage for ruminant feeding in northern China. This study examined the effects of harvest time and added molasses on nutritional content, ensiling characteristics and in vitro degradation of whole crop wheat (WCW).

Methods: Fresh WCW at the milk-ripe stage was harvested at $0700 \mathrm{~h}$ (i.e., in the morning [Mo]) and $1700 \mathrm{~h}$ (i.e., in the afternoon [Af]), and then immediately used to prepare silage and make hay. Commercial molasses was added to Af WCW at 0\%, 2\%, 4\%, and 6\% (fresh weight) proportions. The WCW treated with molasses was mixed thoroughly prior to ensiling. Results: Dry matter (DM), neutral detergent fiber, water soluble carbohydrate (WSC) content ( $\mathrm{p}<0.01)$, accumulative gas production in $72 \mathrm{~h}\left(\mathrm{GP}_{72 \mathrm{~h}}, 77.46 \mathrm{~mL} / \mathrm{g}\right.$ vs $\left.95.15 \mathrm{~mL} / \mathrm{g}\right)$ and dry matter disappearance in vitro $(69.15 \%$ vs $76.77 \%)$ were lower $(\mathrm{p}<0.05)$, while crude protein (CP) content was higher for WCW silage (WCWS) compared to WCW ( $\mathrm{p}<0.01)$. The propionic acid and butyric acid concentrations in WCWS from Mo WCW were $1.47 \%$ and $0.26 \%$, respectively. However, the propionic and butyric acid concentrations were negligible, while the ammonia nitrogen/total nitrogen $\left(\mathrm{NH}_{3}-\mathrm{N} / \mathrm{TN}, \mathrm{p}<0.01\right)$ concentration was lower and the rate of gas production at $50 \%$ of the maximum $(17.05 \mathrm{~mL} / \mathrm{h}$ vs $13.94 \mathrm{~mL} / \mathrm{h}, \mathrm{p}<0.05)$ was higher for Af WCWS compared to Mo WCWS. The incubation fluid's $\mathrm{NH}_{3}-\mathrm{N}$ concentration was lower in WCWS and Af WCW compared to Mo WCW $(\mathrm{p}<0.05)$. The CP and WSC content increased with increasing molasses levels $(\mathrm{p}<0.05)$. Furthermore, the $\mathrm{pH}(\mathrm{p}<0.01)$ and time when gas production was $50 \%$ of the maximum $(2.78 \mathrm{~h}$ vs $3.05 \mathrm{~h}, \mathrm{p}<0.05)$ were lower in silage treated with $4 \%$ molasses than silage without molasses.

Conclusion: Harvesting wheat crops in the afternoon and adding molasses at $4 \%$ level to WCW optimally improved ensiling characteristics, leading to well-preserved silage.

Keywords: Harvest Time; Molasses Addition; Nutritional Content; Ensiling Characteristics; In vitro Fermentation; Whole Crop Wheat

\section{INTRODUCTION}

Silage is commonly used for fodder as high-quality roughage for herbivorous domestic animals. During the ensiling process, soluble carbohydrates in the forages can be fermented into organic acids, mainly with Lactobacillus, which can cause a reduction in $\mathrm{pH}$ and inhibit the growth of several harmful microorganisms; as such, fresh forages can be preserved for a long time [1]. The quantities of Lactobacillus and water soluble carbohydrate (WSC) content are crucial factors that affect silage quality [2]. Other factors—such as plant respiration, enzymes and Clostridium activity—can also affect silage quality [3], while moderate moisture content, sugars and an anaerobic environment are indispensable factors in the ensiling process.

Currently, the main crop material used for ensiling is whole maize crops. As corn prices gradually rise, animal production enterprises tend to seek cheaper alternatives for future use. 
The feeding value of whole crop wheat (WCW) has been studied and considered suitable for ensiling [4]. Among the cereal crops, wheat has become a common silage material in many parts of the world [5,6]. Adamson and Reeve [7] have shown that digestible fiber with a consistent energy value can be provided by WCW silage (WCWS), which has a feeding value that is higher than maize silage and is one of the main sources of roughage for cows. Weinberg et al [8] found that WCWS made at the milk or gold ripeness stages had a high nutritional value, with about $30 \%$ to $35 \%$ dry matter (DM) content, and it is also rich in sugar and protein. However, there is scant literature on the influence of harvest time on ensiling profiles.

Molasses is a by-product of the sugar-refining industry, with a WSC content of $40 \%$ to $46 \%$ (mainly sucrose). It provides fermentation substrates for the proliferation of Lactobacillus during the ensiling process and is often used to promote silage fermentation [9]. It has been reported that molasses can be added to improve the degradation of structural carbohydrates $[2,10]$ and increase the hemicellulose content in silage to improve its digestibility [11]. Baytok et al [10] concluded that adding molasses to silage could effectively prevent the digestion of WSC and DM, significantly reduce silage $\mathrm{pH}$ and ammonia nitrogen $\left(\mathrm{NH}_{3}-\mathrm{N}\right)$ content and improve silage's palatability to ruminant animals. Rezaei et al [12] found that adding molasses to ensiled Amaranthus hypochondriacus reduced the $\mathrm{pH}$, butyric acid content, $\mathrm{NH}_{3}-\mathrm{N}$ content and cytoderm components and increased WSC content, lactic acid content, gas production levels and degradation kinetic parameters in vitro. Molasses can also improve silage quality and positively influence milk yield and composition when used as a source of energy in feed [13].

China is the world's largest wheat producer [4]. In northern China, a large amount of wheat straw is produced. This straw has lower utilisation efficiency compared with maize stalks, which are commonly used as a feed crop. However, as domestic wheat prices have declined recently, wheat offers an alternative for feeding systems. Therefore, the present study aims to investigate the effects of harvest time and the proportions of added molasses on the nutritional content and ensiling characteristics of WCW, as well as evaluate the rumen degradation of wheat hay and silage with the in vitro gas production technique, using wheat from northern China.

\section{MATERIALS AND METHODS}

\section{Experimental materials and design}

Fresh WCW at the milk-ripe stage was harvested at $0700 \mathrm{~h}$ and $1700 \mathrm{~h}$ from cropland in Zhuozhou City, Hebei Province, China. The fresh WCW samples harvested in the morning (Mo) were used to prepare silage and make hay immediately. The WCW harvested in the afternoon (Af) was harvested between sunlight until $1700 \mathrm{~h}$ for ensiling and to make hay. Weather conditions were recorded as sunny, with an average temperature of $32^{\circ} \mathrm{C}$, an average temperature-humidity index of $41 \%$ and a wind speed of 3.4 to $5.4 \mathrm{~m} / \mathrm{s}$. For the Af WCW, commercial molasses (Nanning Zhicheng Agricultural Science and Technology Co. Ltd., Nanjing, China, 52\% WSC/DM) was added in proportions of $0 \%, 2 \%, 4 \%$, and $6 \%$ (fresh weight). The WCW treated with molasses was then mixed thoroughly prior to ensiling.

The wheat hay was made from samples of Mo and Af WCW. Crop samples were spread out evenly in a forced-air oven and rapidly dried at $65^{\circ} \mathrm{C}$ to a constant weight. The obtained WCW hay was ground to pass through a 1-mm sieve and stored for further chemical analysis. To make the silage, the wheat crop material was chopped into lengths of about 3 to $5 \mathrm{~cm}$ (prevent the wheat kernels dropping off). Approximately $0.5 \mathrm{~kg}$ of this blended WCW was placed in polyethylene bag $(28 \mathrm{~cm} \times 40 \mathrm{~cm})$, tightly sealed using a vacuum-sealing machine to remove the air and then stored in a dark place (three bags per treatment). After two months of ensiling, representative samples were removed for further chemical analysis and in vitro gas production testing.

\section{In vitro gas production technique}

Buffer solution modulation: Buffer solutions were prepared as described by Menke et al [14] to include a trace-element solution, a carbonic acid buffer solution, a phosphate buffer solution, a sodium sulfide reducing solution $\left(\mathrm{Na}_{2} \mathrm{~S}\right)$ and a resazurin indicator.

Rumen fluid collection and management: The experimental protocol was approved by the Ethics Committee on the Use and Care of Animals at China Agricultural University (Beijing, China). About $1 \mathrm{~h}$ before the morning feeding, rumen fluid was collected from four rumen-cannulated experimental cows and then filtered through four layers of cheesecloth. The filtrate was kept at $39^{\circ} \mathrm{C}$ in a thermostatically controlled water bath and then added to the prepared buffer solution at a ratio of 1:2 to obtain the mixed artificial rumen culture medium. The solution then stirred thoroughly using a magnetic stirrer, with carbon dioxide $\left(\mathrm{CO}_{2}\right)$ aerated through it again.

In vitro gas production determination: The accumulated gas was measured in real-time using the 64-pathway AGRS-III in vitro rumen fermentation apparatus, which was independently developed by China Agricultural University. The WCW hay and silage were in vitro incubated as sole substrate material without additional concentrate. Freeze-dried samples were ground to pass through a 2-mm screen for the following incubation process. About $0.5 \mathrm{~g}$ of the sample was weighed and placed into a fermentation bottle. After adding $75 \mathrm{~mL}$ of the artificial rumen culture medium with $\mathrm{CO}_{2}$ aerated through it, the bottle was immediately sealed with a rubber plug and then connected to the in vitro fermentation apparatus to measure gas production continuously for $72 \mathrm{~h}$ at $39^{\circ} \mathrm{C}$. The culture bottles 
were shaken gently every $12 \mathrm{~h}$ during the experimental period. In vitro incubation was conducted in one run involving triplicate samples for each substrate treatment. Simultaneously, three blank control samples containing only inoculated medium with no substrate addition were incubated.

The gas production time and accumulated gas in each fermentation bottle were automatically recorded by the AGRS-III apparatus. As the data on the accumulated gas from different treatments with time was non-linear, the following exponential function model, proposed by Ørskov and McDonald [15] was used:

$$
\mathrm{GP}_{\mathrm{t}}=\left[1-\mathrm{e}^{-\mathrm{GPR}(\mathrm{t} \text {-lag }}\right] \times \mathrm{IMGP}
$$

in which $\mathrm{GP}_{\mathrm{t}}$ is the accumulated gas over time $\mathrm{t}(\mathrm{mL} / \mathrm{g}, \mathrm{DM}$ basis); GPR is the rate of gas production $(\mathrm{mL} / \mathrm{h})$; $\mathrm{t}$ is the gas production time $(\mathrm{h})$; lag is the lag time of gas production $(\mathrm{h})$ and IMGP is the ideal maximum gas production $(\mathrm{mL} / \mathrm{g})$.

The rate of gas production at $50 \%$ of the maximum (AGPR) was calculated as follows:

$$
\mathrm{AGPR}=\mathrm{IMGP} \times \mathrm{GPR} /(\log 2+\mathrm{GPR} \times \operatorname{lag})
$$

In vitro fermentation product: After $72 \mathrm{~h}$ of continuous fermentation, the fermentation gas production recording system was turned off, and the $\mathrm{pH}$ of the incubation fluid was immediately measured. The incubation fluid and residual substrate in the bottle then were filtered through a dried and weighed nylon bag (about 200 mesh), and the filtrate was collected. The fermentation substrate with the nylon bag was rinsed with distilled water and dried at $65^{\circ} \mathrm{C}$ for $48 \mathrm{~h}$. The in vitro DM disappearance (IVDMD) was calculated based on the differences in DM content of substrate before and after incubation. About $1.0 \mathrm{~mL}$ of the filtrate was centrifuged at $3,000 \times \mathrm{g}$ for $5 \mathrm{~min}$; then, approximately $500 \mu \mathrm{L}$ of the supernatant liquid was acidified with $150 \mu \mathrm{L}$ of $25 \%$ metaphosphoric acid solution. The mixed liquid then was centrifuged again at $10,000 \times \mathrm{g}$ for $15 \mathrm{~min}$, with the final supernatant liquid collected for further analysis.

\section{Silage lixivium management}

About $20 \mathrm{~g}$ of silage was blended with $180 \mathrm{~mL}$ of sterilised water, juiced using a household juice extractor for $1 \mathrm{~min}$ and then pressed/filtered through four layers of cheesecloth and medium-speed qualitative filter paper. The $\mathrm{pH}$ of the supernatant liquid was immediately measured using a sensitive $\mathrm{pH}$ meter (UB-7, Denver Instrument Co. Ltd., Denver, CO, USA).

\section{Chemical analysis}

Dry matter, crude protein (CP), starch and crude ash contents of the samples were measured following Association of Official Analytical Chemists (AOAC) [16] methods. CP was estimated as N×6.25 (Leco FP-528 Nitrogen Analyzer; Leco Corp., St.
Joseph, MI, USA). Neutral detergent fiber (NDF) and acid detergent fiber $(\mathrm{ADF})$ were measured according to Van Soest et al [17]. Heat-stable $\alpha$-amylase was used in the NDF extraction procedure. WSC was measured using the anthrone-sulfuric acid colorimetric method as described by McDonald et al [18].

Ammonia nitrogen $\left(\mathrm{NH}_{3}-\mathrm{N}\right)$ was measured using a spectrophotometer (UV-1700, Shimadzu Corp., Tokyo, Japan) as described by Broderick and Kang [19]. The concentration of volatile fatty acid (VFA) was measured using a gas chromatograph (GC-2014, Shimadzu Corp., Tokyo, Japan). The lactic acid concentration was measured using the p-hydroxydiphenyl colorimetric method described by Barker and Summerson [20].

\section{Statistical analysis}

The data on nutrient composition, fermentation characteristics and in vitro rumen degradation were analyzed using one-way analysis of variance from the general linear model procedures of SPSS statistical software (version 15, SPSS Inc., Chicago, IL, USA). Notably, fermentation characteristics and in vitro rumen degradation were analyzed with three runs of in vitro batch cultures for each ensiling sample. Differences between the means were tested for significance using the Student-NewmanKeuls method. In this study, an extremely significant difference was declared for $\mathrm{p}<0.01$, and a significant difference for $\mathrm{p}<0.05$, with $\mathrm{p}<0.10$ being considered a tendency.

\section{RESULTS}

The nutritional content of the sampled WCW and WCWS (\% of DM) is shown in Table 1. Significant differences between Mo WCW and Af WCW were observed in DM, crude ash, $\mathrm{NDF}$ and ADF content (37.11\% vs $39.55 \%, 6.24 \%$ vs $5.31 \%$ $43.14 \%$ vs $40.91 \%$, and $23.25 \%$ vs $21.22 \%$, respectively, $\mathrm{p}<0.01$ ). DM (31.89\% vs $37.11 \%)$, NDF ( $41.12 \%$ vs $43.14 \%$ ) and WSC $(0.35 \%$ vs $5.25 \%)$ content was lower, while CP content $(9.49 \%$ vs $8.6 \%$ ) was higher ( $\mathrm{p}<0.01)$, for Mo WCWS compared to Mo WCW. DM (35.02\% vs $39.55 \%)$ and $\mathrm{ADF}(24.55 \%$ vs $21.22 \%)$ content was lower, while crude ash $(5.96 \%$ vs $5.31 \%$ and WSC $(1.11 \%$ vs $6.67 \%)$ content was higher $(\mathrm{p}<0.01)$, for Af WCWS compared to Af WCW.

The fermentation quality parameters of WCWS are shown in Table 2. The propionic and butyric acid concentrations for Mo WCWS were $1.47 \%$ and $0.26 \%$, respectively. However, they were negligible in Af WCWS. The ammonia nitrogen/ total nitrogen $\left(\mathrm{NH}_{3}-\mathrm{N} / \mathrm{TN}\right)$ concentration $(6.17 \%$ vs $9.15 \%)$ in Af WCWS was also lower than those in WCWS from Mo WCW $(\mathrm{p}<0.01)$.

The $\mathrm{CP}$ and crude ash contents increased $(\mathrm{p}<0.05)$ with an increasing level of molasses in the silage, but the WSC content in all silages treated with molasses was lower than those without molasses (Table 3). No significant differences from added molasses were observed in terms of DM, NDF, and ADF ( $p>$ 
Table 1. Nutrient contents of WCW and WCWS

\begin{tabular}{lcccccr}
\hline \multirow{2}{*}{ Items } & \multicolumn{2}{c}{ Harvest time } & \multirow{2}{*}{ SEM } & \multirow{2}{*}{ p-value } \\
\cline { 2 - 4 } & Mo WCW & Mo WCWS & Af WCW & Af WCWS & & 0.41 \\
Dry matter (\% FM) & $37.11^{\mathrm{b}}$ & $31.89^{\mathrm{c}}$ & $39.55^{\mathrm{a}}$ & $35.02^{\mathrm{c}}$ & $<0.01$ \\
Crude protein (\% DM) & $8.60^{\mathrm{b}}$ & $9.49^{\mathrm{a}}$ & $8.79^{\mathrm{b}}$ & $9.10^{\mathrm{ab}}$ & 0.18 & $<0.01$ \\
Crude ash (\% DM) & $6.24^{\mathrm{a}}$ & $6.12^{\mathrm{a}}$ & $5.31^{\mathrm{b}}$ & $5.96^{\mathrm{a}}$ & 0.06 & $<0.01$ \\
Neutral detergent fiber (\% DM) & $43.14^{\mathrm{a}}$ & $41.12^{\mathrm{b}}$ & $40.91^{\mathrm{b}}$ & $43.04^{\mathrm{b}}$ & 0.76 & $<0.01$ \\
Acid detergent fiber (\% DM) & $23.25^{\mathrm{a}}$ & $23.54^{\mathrm{a}}$ & $21.22^{\mathrm{b}}$ & $24.55^{\mathrm{a}}$ & 0.43 & $<0.01$ \\
Water soluble carbohydrate (\% DM) & $5.25^{\mathrm{a}}$ & $0.35^{\mathrm{b}}$ & $6.67^{\mathrm{a}}$ & $1.11^{\mathrm{b}}$ & 0.56 & $<0.01$ \\
Starch (\% DM) & 7.21 & 5.88 & 7.77 & 5.12 & 1.09 & 0.14 \\
\hline
\end{tabular}

WCW, whole crop wheat; WCWS, whole crop wheat silage; Mo, morning; Af, afternoon; SEM, standard error of mean; FM, fresh material; DM, dry matter.

${ }^{a-c}$ Within a row, values followed by different letters are significantly different $(p<0.05)$.

Table 2. Fermentation characteristics of Mo and AfWCWS

\begin{tabular}{lcccr}
\hline \multirow{2}{*}{ Items } & \multicolumn{2}{c}{ Harvest time } & \multirow{2}{*}{ SEM } & p-value \\
\cline { 2 - 3 } & Mo WCWS & Af WCWS & & \\
\hline pH & 4.11 & 4.09 & 0.01 & 0.52 \\
$\mathrm{NH}_{3}$-N/TN (\%) & $9.15^{\mathrm{a}}$ & $6.17^{\mathrm{b}}$ & 0.71 & $<0.01$ \\
Lactic acid (\% DM) & 9.58 & 9.18 & 0.27 & 0.51 \\
Acetic acid (\% DM) & 1.62 & 1.37 & 0.07 & 0.06 \\
Propionic acid (\% DM) & 1.47 & $\mathrm{ND}$ & - & - \\
Butyric acid (\% DM) & 0.26 & $\mathrm{ND}$ & - & - \\
\hline
\end{tabular}

Mo, morning; Af, afternoon; WCWS, whole crop wheat silage; SEM, standard error of mean; $\mathrm{NH}_{3}-\mathrm{N} / \mathrm{TN}$, ammoniacal nitrogen/total nitrogen; $\mathrm{DM}$, dry matter; ND, not detected.

a,b Within a row, values followed by different letters are significantly different $(p<0.05)$.

$0.10)$ or starch content $(\mathrm{p}=0.09)$. Adding molasses reduced $\mathrm{pH}$ of silage lixivium $(\mathrm{p}<0.01$, Table 4$)$, with the lowest $\mathrm{pH}$ in silage treated with $4 \%$ molasses. The $\mathrm{NH}_{3}-\mathrm{N} / \mathrm{TN}$ concentrations tend to be reduced in silages treated with molasses compared with those of the control silage $(p=0.06)$, but no significant differences were observed in lactic and acetic acid concentrations ( $\mathrm{p}>0.10$ ). No treatment produced propionic nor butyric acids.

Table 5 and Figure 1a show that $\mathrm{GP}_{72 \mathrm{~h}}(77.46 \mathrm{~mL} / \mathrm{g}$ vs 95.15 $\mathrm{mL} / \mathrm{g})$, IMGP (76.56 mL/g vs $95.88 \mathrm{~mL} / \mathrm{g})$, AGPR (11.15 mL/h vs $17.56 \mathrm{~mL} / \mathrm{h}$ ) and IVDMD (69.15\% vs $76.77 \%)$ were lower $(\mathrm{p}<0.05)$ for Mo WCWS compared to Mo WCW. The rate of gas production (GPR) and lag time of gas production of WCWs were higher than those of WCWSs $(p<0.05)$. The lag time of gas production was different between Mo WCW and Af WCW ( $0.47 \mathrm{~h}$ vs $0.56 \mathrm{~h}, \mathrm{p}<0.05)$. In addition, AGPR was lower for Mo WCWS than for that from Af WCW $(13.94 \mathrm{~mL} / \mathrm{h}$ vs 17.05 $\mathrm{mL} / \mathrm{h}, \mathrm{p}<0.05)$. As shown in Table 6, the $\mathrm{pH}$ and acetic, propionic, isobutyric, butyric, isovaleric, and valeric acid contents of the incubation fluid did not change different between treatments ( $\mathrm{p}>0.05)$. The $\mathrm{NH}_{3}-\mathrm{N}$ concentration was lower in Mo WCWS compared to Mo WCW (11.60 mmol/L vs 17.99 $\mathrm{mmol} / \mathrm{L}, \mathrm{p}<0.05)$ but was higher in Mo WCW than in Af WCW (17.99 mmol/L vs $12.05 \mathrm{mmol} / \mathrm{L}, \mathrm{p}<0.05)$.

The study showed that adding molasses reduced the length of time when gas production is $50 \%$ of the maximum (Table 7 ; Figure $1 b)$. This value was lower in silage treated with $4 \%$ molasses than in silages without molasses $(2.78 \mathrm{~h}$ vs $3.05 \mathrm{~h}, \mathrm{p}<0.05)$. Levels of the other fermentation kinetics parameters, IVDMD $\left(\mathrm{p}=0.08\right.$, Table 7), VFA parameters nor $\mathrm{NH}_{3}-\mathrm{N}(\mathrm{p}=0.07$, Table 8 ) in the incubation fluid changed between treatments with different levels of added molasses ( $p>0.05)$. However, adding molasses reduced the $\mathrm{pH}(\mathrm{p}<0.01)$.

\section{DISCUSSION}

Table 3. Effects of molasses addition on nutrient contents of WCWS

\begin{tabular}{|c|c|c|c|c|c|c|}
\hline \multirow{2}{*}{ Items } & \multicolumn{4}{|c|}{ Molasses addition } & \multirow{2}{*}{ SEM } & \multirow{2}{*}{$\mathrm{p}$-value } \\
\hline & $0(\% \mathrm{FM})$ & $2(\% \mathrm{FM})$ & $4(\% \mathrm{FM})$ & $6(\% \mathrm{FM})$ & & \\
\hline Dry matter (\% FM) & 35.02 & 33.87 & 34.31 & 36.42 & 1.13 & 0.37 \\
\hline Crude ash (\% DM) & $5.96^{c}$ & $6.26^{b}$ & $6.74^{a}$ & $6.84^{\mathrm{a}}$ & 0.09 & $<0.01$ \\
\hline Neutral detergent fiber (\% DM) & 43.04 & 42.10 & 41.56 & 39.91 & 1.66 & 0.35 \\
\hline Acid detergent fiber (\% DM) & 24.55 & 23.66 & 23.47 & 22.10 & 1.14 & 0.27 \\
\hline Starch (\% DM) & $5.12^{b}$ & $7.10^{\mathrm{a}}$ & $6.59^{\mathrm{ab}}$ & $7.78^{\mathrm{ab}}$ & 1.30 & 0.09 \\
\hline
\end{tabular}

WCWS, whole crop wheat silage; FM, fresh material; SEM, standard error of mean; DM, dry matter.

a-c Within a row, values followed by different letters are significantly different $(p<0.05)$. 

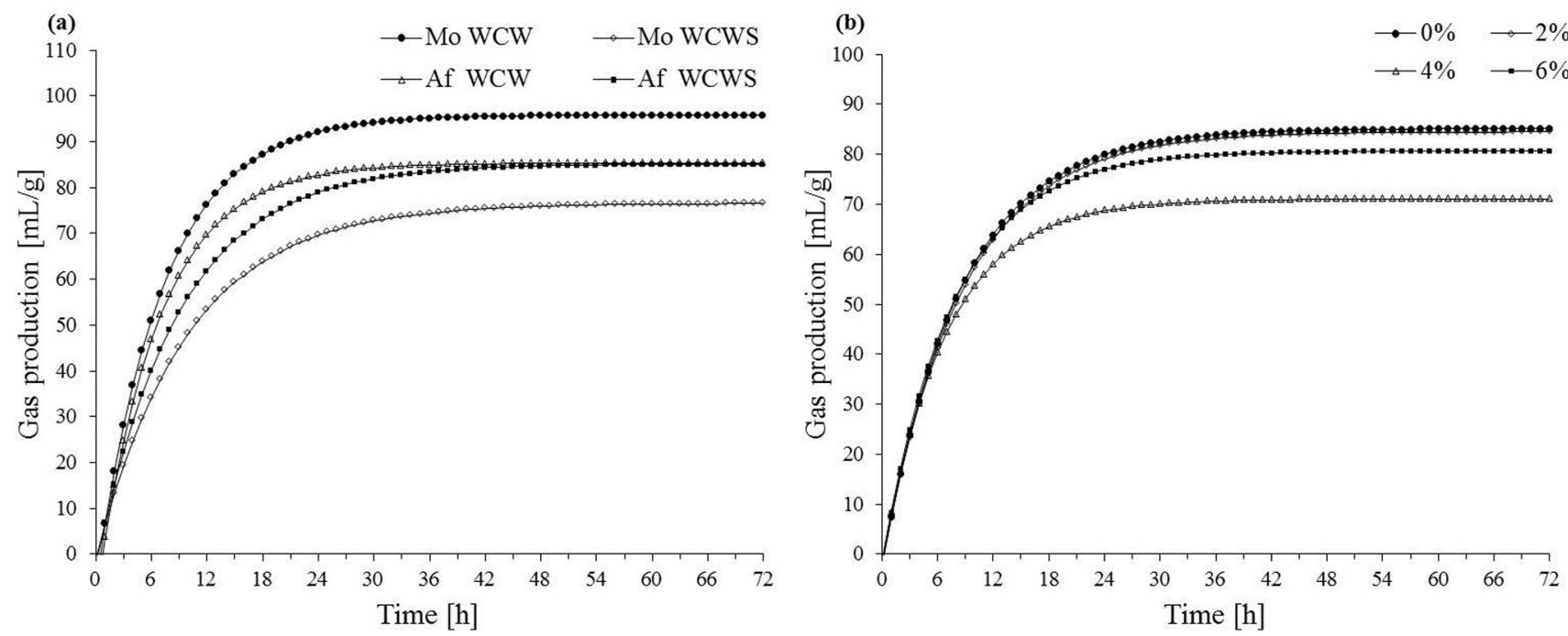

Figure 1. The dynamic curve of accumulative gas production of (a) WCW and WCWS fermentation and (b) molasses treated WCWS fermentation in vitro. Mo, morning; Af, afternoon; WCW, whole crop wheat; WCWS, whole crop wheat silage.

\section{Nutrient content and fermentation characteristics of WCW and WCWS}

Fermentation microorganisms can be divided into beneficial microorganisms (mainly lactic acid bacteria) and those that cause deterioration (such as Enterobacteriaceae and Clostridium) during the ensiling process [2]. During the aerobic phase of ensiling, the microorganisms can consume the nutrients in the silage lixivium, making for rapid proliferation. In the pre-

Table 4. Effects of molasses addition on fermentation characteristics of WCWS

\begin{tabular}{|c|c|c|c|c|c|c|}
\hline \multirow{2}{*}{ Items } & \multicolumn{4}{|c|}{ Molasses addition } & \multirow{2}{*}{ SEM } & \multirow{2}{*}{ p-value } \\
\hline & 0 (\% FM) & 2 (\% FM) & 4 (\% FM) & 6 (\% FM) & & \\
\hline $\mathrm{pH}$ & $4.09^{a}$ & $3.97^{b}$ & $3.96^{\mathrm{b}}$ & $3.97^{b}$ & 0.02 & $<0.01$ \\
\hline $\mathrm{NH}_{3}-\mathrm{N} / \mathrm{TN}(\%)$ & 6.17 & 4.54 & 5.64 & 5.08 & 0.25 & 0.06 \\
\hline Lactic acid (\% DM) & 9.18 & 9.58 & 9.90 & 9.43 & 0.21 & 0.54 \\
\hline Acetic acid (\% DM) & 1.37 & 1.30 & 1.35 & 1.32 & 0.30 & 0.89 \\
\hline Propionic acid (\% DM) & ND & ND & ND & ND & - & - \\
\hline Butyric acid (\% DM) & ND & ND & ND & ND & - & - \\
\hline
\end{tabular}

WCWS, whole crop wheat silage; FM, fresh material; SEM, standard error of mean; $\mathrm{NH}_{3}-\mathrm{N} / \mathrm{TN}$, ammoniacal nitrogen/total nitrogen; DM, dry matter; ND, not detected.

$a, b$ Within a row, values followed by different letters are significantly different $(p<0.05)$.

Table 5. IVDMD and gas production and in vitro fermentation kinetic parameters of WCW and WCWS after fermentation for $72 \mathrm{~h}$

\begin{tabular}{|c|c|c|c|c|c|c|}
\hline \multirow{2}{*}{ Items } & \multicolumn{4}{|c|}{ Harvest time } & \multirow{2}{*}{ SEM } & \multirow{2}{*}{ p-value } \\
\hline & Mo WCW & Mo WCWS & Af WCW & Af WCWS & & \\
\hline IVDMD (\%) & $76.77^{\mathrm{a}}$ & $69.15^{b}$ & $75.29^{\mathrm{a}}$ & $72.74^{\mathrm{ab}}$ & 1.67 & 0.04 \\
\hline $\mathrm{GP}_{72 \mathrm{~h}}(\mathrm{~mL} / \mathrm{g})$ & $95.15^{\mathrm{a}}$ & $77.46^{\mathrm{b}}$ & $91.67^{\mathrm{a}}$ & $86.34^{a b}$ & 2.58 & 0.02 \\
\hline $\operatorname{IMGP}(\mathrm{mL} / \mathrm{g})$ & $95.88^{\mathrm{a}}$ & $76.56^{b}$ & $91.65^{\mathrm{a}}$ & $85.17^{\mathrm{ab}}$ & 2.69 & 0.01 \\
\hline \multicolumn{7}{|c|}{ Fermentation kinetic parameters } \\
\hline $\operatorname{Lag}(h)$ & $0.47^{b}$ & $0.10^{c}$ & $0.56^{\mathrm{a}}$ & $0.21^{c}$ & 0.05 & 0.01 \\
\hline Halftime (h) & 3.15 & 3.07 & 3.20 & 3.05 & 0.07 & 0.40 \\
\hline $\mathrm{GPR}(\mathrm{mL} / \mathrm{h})$ & $0.14^{\mathrm{a}}$ & $0.10^{b}$ & $0.14^{\mathrm{a}}$ & $0.11^{b}$ & 0.01 & 0.02 \\
\hline $\operatorname{AGPR}(\mathrm{mL} / \mathrm{h})$ & $17.56^{\mathrm{a}}$ & $11.15^{b}$ & $17.05^{\mathrm{a}}$ & $13.94^{\mathrm{a}}$ & 0.76 & 0.01 \\
\hline
\end{tabular}

IVDMD, dry matter disappearance in vitro; WCW, whole crop wheat; WCWS, whole crop wheat silage; Mo, morning; Af, afternoon; SEM, standard error of mean; GP72h, accumulative gas production in $72 \mathrm{~h}$; IMGP, the ideal maximum gas production; Lag, the lag time of gas production; GPR, the rate of gas production; AGPR, rate of gas production when it was $50 \%$ of the maximum.

a-c Within a row, values followed by different letters are significantly different $(p<0.05)$. 
Table 6. In vitro fermentation characteristics of WCW and WCWS after fermentation for $72 \mathrm{~h}$

\begin{tabular}{|c|c|c|c|c|c|c|}
\hline \multirow{2}{*}{ Items } & \multicolumn{4}{|c|}{ Harvest time } & \multirow{2}{*}{ SEM } & \multirow{2}{*}{$\mathrm{p}$-value } \\
\hline & Mo WCW & Mo WCWS & Af WCW & Af WCWS & & \\
\hline $\mathrm{pH}$ & 6.67 & 6.65 & 6.66 & 6.72 & 0.14 & 0.05 \\
\hline $\mathrm{NH}_{3}-\mathrm{N}(\mathrm{mmol} / \mathrm{L})$ & $17.99^{\mathrm{a}}$ & $11.60^{b}$ & $12.05^{b}$ & $16.09^{b}$ & 2.00 & 0.04 \\
\hline Acetic acid (mmol/L) & 32.12 & 25.53 & 32.72 & 26.53 & 7.32 & 0.68 \\
\hline Propionic acid (mmol/L) & 12.48 & 10.79 & 12.59 & 10.68 & 1.78 & 0.65 \\
\hline Isobutyric acid (mmol/L) & 0.53 & 0.42 & 0.52 & 0.43 & 0.15 & 0.81 \\
\hline Butyric acid (mmol/L) & 4.81 & 3.17 & 4.77 & 3.46 & 1.43 & 0.55 \\
\hline Isovaleric acid (mmol/L) & 0.99 & 0.74 & 1.02 & 0.78 & 0.32 & 0.68 \\
\hline Valeric acid (mmol/L) & 0.80 & 0.61 & 0.86 & 0.67 & 0.25 & 0.70 \\
\hline
\end{tabular}

WCW, whole crop wheat; WCWS, whole crop wheat silage; Mo, morning; Af, afternoon; SEM, standard error of mean; $\mathrm{NH}_{3}-\mathrm{N}$, ammoniacal nitrogen.

${ }^{a, b}$ Within a row, values followed by different letters are significantly different $(p<0.05)$.

sent study, we visually observed that a large amount of gas was produced during the ensiling process of fresh WCW sampled in the morning, while it was virtually zero for WCWS from Af WCW. McDonald et al [18] reported that $\mathrm{pH}$ decreases in silages caused by microbe fermentation could restrain the degradation of $\mathrm{CP}$ and $\mathrm{NH}_{3}-\mathrm{N}$ production. Thus, the higher concentration of $\mathrm{NH}_{3}-\mathrm{N} / \mathrm{TN}$ in silage from Mo WCW indicates greater $\mathrm{CP}$ degradation. Therefore, the $\mathrm{CP}$ could be degraded into large amounts of benzopyrole and gas, corresponding with lower acetic acid production [2]. Actually, it showed that carbohydrates (such as WSC) could be degraded into $\mathrm{CO}_{2}$, water and heat by aerobic microbes during early ensiling phase [21]. In addition, the populations of epiphytic microorganisms in silage crops could be affected by forage species, maturity stage, weather and field-wilting [22]. Another study found various airborne microbes generally attach themselves to atmospheric particulates in aerosol form [23], which eventually return to soil, water, animals and plants in the surface. Thus,

Table 7. Effects of molasses addition on IVDMD, gas production and fermentation kinetic parameters of WCWS after fermentation for $72 \mathrm{~h}$

\begin{tabular}{|c|c|c|c|c|c|c|}
\hline \multirow{2}{*}{ Items } & \multicolumn{4}{|c|}{ Molasses addition } & \multirow{2}{*}{ SEM } & \multirow{2}{*}{$p$-value } \\
\hline & $0(\% \mathrm{FM})$ & $2(\% \mathrm{FM})$ & $4(\% \mathrm{FM})$ & $6(\% \mathrm{FM})$ & & \\
\hline IVDMD (\%) & 72.74 & 74.16 & 72.21 & 76.20 & 0.98 & 0.08 \\
\hline $\mathrm{GP}_{72 \mathrm{~h}}(\mathrm{~mL} / \mathrm{g})$ & 86.34 & 86.29 & 70.84 & 81.38 & 4.84 & 0.16 \\
\hline $\operatorname{IMGP}(\mathrm{mL} / \mathrm{g})$ & 85.17 & 84.49 & 71.04 & 80.69 & 4.45 & 0.17 \\
\hline \multicolumn{7}{|c|}{ Fermentation kinetic parameters } \\
\hline $\operatorname{Lag}(\mathrm{h})$ & 0.21 & 0.20 & 0.14 & 0.16 & 0.07 & 0.88 \\
\hline Halftime (h) & $3.05^{\mathrm{a}}$ & $3.05^{\mathrm{a}}$ & $2.78^{b}$ & $2.89^{\mathrm{ab}}$ & 0.06 & 0.04 \\
\hline GPR (mL/h) & 0.11 & 0.11 & 0.14 & 0.12 & 0.01 & 0.16 \\
\hline $\operatorname{AGPR}(\mathrm{mL} / \mathrm{h})$ & 13.94 & 13.50 & 14.15 & 14.48 & 0.73 & 0.81 \\
\hline
\end{tabular}

IVDMD, dry matter disappearance in vitro; WCWS, whole crop wheat silage; FM, fresh material; SEM, standard error of mean; $\mathrm{GP}_{72 \mathrm{~h}}$ accumulative gas production in $72 \mathrm{~h}$; IMGP, the ideal maximum gas production; GPR, the rate of gas production; AGPR, rate of gas production when it was $50 \%$ of the maximum.

$a, b$ Within a row, values followed by different letters are significantly different $(p<0.05)$.

Table 8. Effects of molasses addition on in vitro fermentation characteristics of WCWS after fermentation for $72 \mathrm{~h}$

\begin{tabular}{|c|c|c|c|c|c|c|}
\hline \multirow{2}{*}{ Items } & \multicolumn{4}{|c|}{ Molasses addition } & \multirow{2}{*}{ SEM } & \multirow{2}{*}{$p$-value } \\
\hline & 0 (\% FM) & $2(\% \mathrm{FM})$ & $4(\% \mathrm{FM})$ & 6 (\% FM) & & \\
\hline pH & $6.72^{\mathrm{a}}$ & $6.66^{\mathrm{b}}$ & $6.63^{b}$ & $6.61^{b}$ & 0.02 & $<0.01$ \\
\hline $\mathrm{NH}_{3}-\mathrm{N}(\mathrm{mmol} / \mathrm{L})$ & 16.09 & 17.71 & 11.71 & 13.32 & 2.13 & 0.07 \\
\hline Acetic acid (mmol/L) & 26.53 & 31.69 & 35.11 & 37.89 & 11.68 & 0.84 \\
\hline Propionic acid (mmol/L) & 10.68 & 12.03 & 12.87 & 13.4 & 2.62 & 0.85 \\
\hline Isobutyric acid (mmol/L) & 0.43 & 0.51 & 0.57 & 0.63 & 0.22 & 0.85 \\
\hline Butyric acid (mmol/L) & 3.46 & 4.23 & 4.76 & 5.51 & 2.16 & 0.86 \\
\hline Isovaleric acid (mmol/L) & 0.78 & 0.94 & 1.11 & 1.24 & 0.53 & 0.85 \\
\hline Valeric acid (mmol/L) & 0.67 & 0.8 & 0.85 & 1.09 & 0.42 & 0.81 \\
\hline
\end{tabular}

WCWS, whole crop wheat silage; FM, fresh material; SEM, standard error of mean; $\mathrm{NH}_{3}-\mathrm{N}$, ammoniacal nitrogen.

${ }_{a, b}$ Within a row, values followed by different letters are significantly different $(p<0.05)$. 
many ambient atmospheric microorganisms might sedimentate and settle on the surface of wheat crop, especially after a quiet night before harvest day. Sunlight radiation has an obvious germicidal effect on microbes, and solar irradiance is highest around noon during the summer, which would be conductive to low airborne microbe content [24]. Thus, we surmise that high temperatures and intense daytime sunlight radiation in the summer probably reduced the microorganisms in the crop material, contributing to improved microbial ensiling fermentation from the Af WCWS compared to Mo WCWS and its high gas production.

Superior quality silage contains a lot of lactic acid, little acetic acid and butyric acid $[18,25]$. The present experiment revealed that all ensiling treatments yielded high-quality silages. Unlike silage from Mo WCW, propionic and butyric acids were not detected in the silage from Af WCW. This might be explained by the higher production of lactic acid caused by the relatively sufficient amounts of fermentation substrates in the Af WCW while the $\mathrm{pH}$ fell rapidly, thereby inhibiting the production of harmful microorganisms (e.g., Clostridium butyricum) [18]. The lactic acid in the silage from Mo WCW was fermented by Clostridium, which may have been responsible for the secondary fermentation (mainly butyric acid fermentation) at the end of ensiling. Baytok et al [10] reported that the $\mathrm{NH}_{3}-\mathrm{N}$ concentration could be used to reveal the extent of proteolysis in silage. Williams et al [26] demonstrated that lower $\mathrm{NH}_{3}$ content in well-fermented silage could result in the greater preservation of forage protein. The concentration of $\mathrm{NH}_{3}-\mathrm{N} / \mathrm{TN}$ in silage from Af WCW indicated that the extent of degradation of $\mathrm{CP}$ was lower than that in silage from Mo WCW, leading to more extensive fermentation and a greater loss of protein. In addition, due to the strong sunlight and hot temperature, WCWS from a slightly wilting crop contained higher fermentation substrates, which might improve ensiling profiles. However, Williams et al [26] reported that the ensiling fermentation of wilted forage was restricted, with lower levels of organic acids and $\mathrm{NH}_{3}$. The study indicated that field-wilting raised the DM content in wheat forage and had been considered to be an effective postharvest strategy to improve silage quality [26].

\section{Effects of added molasses on nutrient content and fermentation characteristics of WCWS}

Compared with other groups, WCWS treated with $6 \%$ level of molasses contains more DM, but not significant. A similar observation also was reported by McDonald et al [18], who demonstrated that molasses addition could stimulate lactic acid production, reduce DM loss and improve silage quality. Consistent with the current research, previous literature showed that corn silage treated with molasses significantly enhanced $\mathrm{CP}$ concentration, suggesting that increased CP content in molasses-treated silages might be attributed to the relatively higher CP concentration in molasses [10]. However, the addition of molasses could stimulate fermentation to produce lactic acid, which accelerates the reduction in $\mathrm{pH}$, thereby inhibiting the activity of proteolysis and pernicious microorganisms that are sensitive to low $\mathrm{pH}$ values.

Generally, the WSC in silage is mainly consumed during lactic acid production. Therefore, adding molasses affects the predominant Lactobacillus species during the ensiling process, simultaneously leading to biochemical changes and changing the proportions of carbohydrates in the silage. Adding molasses effectively can compensate for an insufficient fermentation substrate in silage materials, thereby improving the preservation quality of silage [2]. Rezaei et al [12] added different proportions of molasses to Amaranthus hypochondriacus silage, suggesting that molasses might be responsible for reducing $\mathrm{pH}$ and cytoderm components and increasing WSC content. NDF and ADF content in WCWS showed a tendency to decrease with increasing levels of added molasses, but not to a significant degree. Similar results were found by Bolsen et al [2] and Baytok et al [10], who also suggested that decreases in NDF and ADF content might be attributable to increased cytoderm digestion resulting from increased silage fermentation caused by the application of molasses.

Acetic, propionic and butyric acid levels were lower, while lactic acid content was higher, for the molasses-treated silages in this study compared with silages defined as good to very good as reported by Kilic [25]; the silages in this study were also consistent with the another literature in terms of its good ensiling quality [18]. The $\mathrm{NH}_{3}-\mathrm{N} / \mathrm{TN}$ content in molasses-treated silage resembled the $5 \%$ guideline proposed by Chamberlain and Wilkinson [27], indicating the good fermentation quality of the silage. Generally, all treatments using added molasses in the present study showed good fermentation and yielded excellent quality silage. The application of molasses reduced $\mathrm{pH}$ achieving a lowest value in silage treated with $4 \%$ molasses. Baytok et al [10] and Rezaei et al [12] found that adding molasses can reduce $\mathrm{pH}$ in silage, which supports the results of the current study. Correspongding with Af WCWS, propionic and butyric acid levels were not detected in silage treated with added molasses, which may be attributable to the heterofermentative fermentation resulting from added molasses [28] as well as the suppressed activity of harmful microorganisms (e.g., Clostridium butyricum) caused by rapidly reduced $\mathrm{pH}$ [18]. This explanation is also supported by a study by Rezaei et al [12], which found that added molasses increases the quantity of Lactobacillus, resulting in reductions in $\mathrm{pH}$ and butyric acid concentration.

Our results have demonstrated that adding molasses reduced $\mathrm{NH}_{3}-\mathrm{N} / \mathrm{TN}$ concentrations in silage, while silage material treated with $4 \%$ molasses provided higher degradation of protein compared with the other treatments. Silage with a high $\mathrm{NH}_{3}-\mathrm{N} / \mathrm{TN}$ content could smell foul, thereby reducing its qual- 
ity and nutrient intake [29]. However, data from silage with $6 \%$ added molasses showed a higher concentration of $\mathrm{NH}_{3}-$ $\mathrm{N} / \mathrm{TN}$. This may be attributable to the degradation of a smaller amount of $\mathrm{CP}$, especially non-protein nitrogen in molasses [18]. Baytok et al [10] suggested that $\mathrm{NH}_{3}-\mathrm{N}$ concentration could indicate the extent of proteolysis, and it was numerically higher in silage treated with molasses. In the present study, adding molasses reduced $\mathrm{NH}_{3}-\mathrm{N} / \mathrm{TN}$ concentrations in silage, indicating that treatments with molasses restrained proteolysis causing less protein loss than treatments without molasses. Therefore, we can conclude that WCW treated with molasses showed better ensiling properties.

\section{In vitro gas production kinetics and fermentation characteristics of WCWS}

As shown in gas production graph (Figure 1), the cumulative gas production curve reached a plateau at about $36 \mathrm{~h}$, indicating that substrate degradation was nearly finished. The accumulated products' adverse effect on microbe was not strong in the present study, as the $\mathrm{pH}$ was within the scope of normal rumen conditions, which would have little effect on microbial fermentation. Moreover, when WCW hay or silage with no extra concentrate addition was evaluated, the incubation was extended time due to the high cellulose content in the fermentation substrate. Presently, the $\mathrm{GP}_{72 \mathrm{~h}}$ of WCW hay was higher than that of silage, which was consistent with DM digestibility data. In a study on leguminous Sesbania forage, Nsahlai et al [30] concluded that ideal maximum gas production was negatively related to NDF, lignin and hemicellulose content, but positively correlated with CP content.

The NDF content in Mo WCWS was higher than that of Af WCW, and the $\mathrm{GP}_{72 \mathrm{~h}}$ of WCWS from Af WCW was significantly higher than that of WCWS from Mo WCW. We speculated that the limited fermentation might contribute to the present results. Furthermore, the detrimental microorganisms attached to fresh Mo WCW may have caused greater deterioration of the silage, which also leads to greater energy loss, thereby reducing $\mathrm{GP}_{72 \mathrm{~h}}$. In the present experiment, the data on gas production lag time and the time when gas production is at $50 \%$ of the maximum demonstrated that wheat plants can be better used by microorganisms after ensiling. Although some nutrients in the feed could be fermented into components that can be easily used by rumen microorganisms during the ensiling process, some nutrients were lost because most of the soluble sugar and the small amount of starch were degraded. Thus, the GPR, AGPR and GP ${ }_{72 h}$ in WCWS were lower than those in WCW. However, contrary to our results, the in vitro gas production kinetic parameters were not found to be significantly different between wheat crop and wheat silage [25].

Adding molasses generally reduced the time when gas production was at $50 \%$ of the maximum; its value was significantly lower in silage treated with $4 \%$ molasses than in silage treated without molasses. The supplied commercial molasses has high evaluated nutrients, and the easier utilisation of nutrients in silage can be explained by the better fermentation promoted by adding molasses. Despite all this, the other in vitro fermentation kinetic parameters were not significantly different between treatments. Contrary to our results, Rezaei et al [12] found that adding molasses to Amaranthus hypochondriacus silage increased lactic acid content, in vitro gas production and other degradation parameters.

The fermentation products from carbohydrates in the rumen were mainly VFAs. Acetic, propionic and butyric acids were predominant, accounting for about $95 \%$ of the total VFAs. Therefore, the fermentation of carbohydrates in the rumen could be accurately reflected by determining the concentrations of these acids. No differences between Mo WCWS and Af WCWS were found in terms of the organic acids present in the in vitro fermented fluids. However, when Williams et al [26] fed steers wilted wheat silage, they found some changes in the ruminal VFA fermentation, with a greater concentration of acetic acid and a lower concentration of propionic acid compared with silage in control group. Williams et al [26] also reported that wilted silage produced a lower concentration of ruminal $\mathrm{NH}_{3}-\mathrm{N}$, which was consistent with our results. This may reflect a tendency for greater ruminal digestion and utilisation of $\mathrm{NH}_{3}-\mathrm{N}$ by microbes, indicating that WCW material harvested in the afternoon, treated with sunlight illumination and wilting, can enhance the nutritional value of wheat silage.

In conclusion, WCWS from Af WCW was better than silage from Mo WCW, and the $4 \%$ molasses added to the wheat crop was cost effective in improving the fermentation process and reducing nutrient loss. Af WCW can improve DM and WSC content and fermentation, suggesting that it is as an effective pre-ensiling method to enhance silage quality. Although ensiling may cause a certain amount of nutrient loss, silage provides better rumen fermentation than fresh wheat crop. Adding molasses can supply WSCs in silage, improving ensiling quality. Molasses added to WCW at the $4 \%$ level was essential to produce well-preserved silage.

\section{CONFLICT OF INTEREST}

We certify that there is no conflict of interest with any financial organization regarding the material discussed in the manuscript.

\section{ACKNOWLEDGMENTS}

This work was supported by the earmarked fund for China Agriculture Research System (CARS-37) and Special Fund for Agro-scientific Research in the Public Interest (201303144). 


\section{REFERENCES}

1. Weddell JR. Add-SaFe as a silage additive for big bale silage. Occasional Symposium-British Grassland Society, 1991;25: 228-9.

2. Bolsen KK, Ashbell G, Weinberg ZG. Silage fermentation and silage additives - review -. Asian-Australas J Anim Sci 1996;9: 483-94.

3. Dolezal P, Zeman L, Dvoracek J. Quality of silages and silage additives. Krmivarstvi Czech Republic; 2001. p. 16-20.

4. Ni K, Wang Y, Cai Y, Pang H. Natural lactic acid bacteria population and silage fermentation of whole-crop wheat. AsianAustralas J Anim Sci 2015;28:1123-32.

5. Weinberg ZG, Chen Y, Solomon R. The quality of commercial wheat silages in Israel. J Dairy Sci 2009;92:638-44.

6. Bal EBB, Bal MA. Effects of chemical additives and ensiling time on whole plant wheat silage microbial profiles inferred by phenotypic and $16 \mathrm{~S}$ ribosomal DNA analyses. World J Microb Biotechnol 2012;28:767-76.

7. Adamson AH, Reeve A. Nutritional evaluation of whole-crop wheat. In: Whole-crop cereals. Aberystwyth, UK: Chalcombe Publications; 1992. p. 85-96.

8. Weinberg ZG, Ashbell G, Hen Y, Harduf Z. Ensiling whole wheat for ruminant feeding at different stages of maturity. Anim Feed Sci Technol 1991;32:313-20.

9. Lima R, Lourenco M, Diaz RF, Castro A, Fievez V. Effect of combined ensiling of sorghum and soybean with or without molasses and lactobacilli on silage quality and in vitro rumen fermentation. Anim Feed Sci Technol 2010;155:122-31.

10. Baytok E, Aksu T, Karsli MA, Muruz H. The effects of formic acid, molasses and inoculant as silage additives on corn silage composition and ruminal fermentation characteristics in sheep. Turk J Vet Anim Sci 2005;29:469-74.

11. Shao T, Shimojo M, Wang T, Masuda Y. Effect of additives on the fermentation quality and residual mono- and di-saccharides compositions of Forage Oats (Avena sativa L.) and Italian Ryegrass (Lolium multiflorum Lam.) silages. Asian-Australas J Anim Sci 2005;18:1582-8.

12. Rezaei J, Rouzbehan Y, Fazaeli H. Nutritive value of fresh and ensiled amaranth (Amaranthus hypochondriacus) treated with different levels of molasses. Anim Feed Sci Technol 2009;151: 153-60.

13. Broderick GA, Radloff WJ. Effect of molasses supplementation on the production of lactating dairy cows fed diets based on alfalfa and corn silage. J Dairy Sci 2004;87:2997-3009.

14. Menke KH, Raab L, Salewski A, et al. The estimation of the digestibility and metabolizable energy content of ruminant feedingstuffs from the gas production when they are incubated with rumen liquor in vitro. J Agric Sci 1979;93:217-22.
15. Ørskov ER, McDonald I. The estimation of protein degradability in the rumen from incubation measurements weighted according to rate of passage. J Agric Sci 1979;92:499-503.

16. AOAC. Official methods of analysis of the AOAC International. 17th edn. Gaithersberg, MD: AOAC International; 2000.

17. Van-Soest PJ, Robertson JB, Lewis BA. Methods for dietary fiber, neutral detergent fiber, and non-starch polysaccharides in relation to animal nutrition. J Dairy Sci 1991;74:3583-97.

18. McDonald P, Henderson AR, Heron SJE. The biochemistry of silage. 2nd edn. Kingston, Kent: Chalcombe Publications; 1991. p. 340.

19. Broderick GA, Kang JH. Automated simultaneous determination of ammonia and total amino acids in ruminal fluid and in vitro media. J Dairy Sci 1980;63:64-75.

20. Barker SB, Summerson WH. The colorimetric determination of lactic acid in biological material. J Biol Chem 1941;138:53554.

21. Ennahar S, Cai Y, Fujita Y. Phylogenetic diversity of lactic acid bacteria associated with paddy rice silage as determined by 16S ribosomal DNA analysis. Appl Environ Microbiol 2003;69: 444-51.

22. Fenton MP. An investigation into the sources of lactic acid bacteria in grass silage. J Appl Microbiol 2008;62:181-8.

23. Reponen TA, Gazenko SV, Grinshpun SA, Willeke K, Cole EC. Characteristics of airborne actinomycete spores. Appl Environ Microbiol 1998;64:3807-12.

24. Tong YY, Lighthart B. Effect of simulated solar radiation on mixed outdoor atmospheric bacterial populations. FEMS Microbiol Ecol 1998;26:311-6.

25. Kilic U. Nutritive values of whole-crop wheat hay and silage and effect of microbial inoculants on in vitro gas production. J Appl Anim Res 2010;37:67-71.

26. Williams CC, Froetschel MA, Ely LO, Amos HE. Effects of inoculation and wilting on the preservation and utilization of wheat forage. J Dairy Sci 1995;78:1755-65.

27. Chamberlain AT, Wilkinson JM. Feeding the dairy cow, 2nd edition. Lincoln, UK: Chalcombe Publications; 2000.

28. Chase LE. Controlling silage quality. In: Cornell nutrition conference for feed manufacture. Ithaca, NY: Cornell University; 1988.

29. Shao T, Ohba N, Shimojo M, Masuda Y. Effects of addition of glucose and sorbic acid on the fermentation quality of guineagrass (Panicum maximum Jacq.) silages. J Fac Agric Kyushu U 2003;47:351-8.

30. Nsahlai IV, Siaw DEKA, Osuji PO. The relationships between gas production and chemical composition of 23 browses of the genus Sesbania. J Sci Food Agric 1994;65:13-20. 